\title{
The effect of supplemental pig milk replacer on carbohydrate metabolism - a review
}

\author{
${ }^{1}$ Georgina Pesti-Asbóth - ${ }^{2}$ Gabriella Novotni-Dankó - ${ }^{2}$ Zsolt Győri - ${ }^{1}$ László Stündl - \\ ${ }^{1}$ Magdolna Mária Szarvas - ${ }^{1}$ Judit Remenyik \\ University of Debrecen Faculty of Agricultural and Food sciences and Environmental Management, \\ ${ }^{1}$ Institute of Food Technology, Debrecen, Hungary \\ ${ }^{2}$ Department of Animal Husbandry, Debrecen, Hungary \\ georgina.asboth@agr.unideb.hu
}

\begin{abstract}
SUMMARY
The aim of this review is to examine the effect of milk supplementation on pigs' carbohydrate metabolism. These parameters regulate the growth of piglets, the nutrient intake and the period of pre-weaning. Due to the increased litter size, the sow milk yield reaches an individual maximum. The individual maximum has not increased proportionally with the number of piglets born alive. The use of liquid milk supplementation may give the opportunity to keep these large litters. The examined hormones are insulin, insulin-like growth factor, growth hormone, growth hormone releasing hormone, ghrelin and leptin. This review seeks to find these hormones' interactions.
\end{abstract}

Keywords: liquid milk replacement, carbohydrate metabolism, Insulin, IGF-1, GH, GHRH, Ghrelin, Leptin

\section{INTRODUCTION}

The increased litter size was the goal in pig production which results a highly-prolific sow lines with a large number of piglets born alive (Sandøe et al. 2012). Growing litter numbers cause concern in health and animal welfare, and these increased litters are challengeable for farmers. Although milk production increases with the demand of the piglets, sow milk yield usually reaches an individual maximum (Algers et al. 1985, King 2000). This individual maximum has not increased proportionally with the number of piglets born alive over the recent decades. The actual milk volume per piglet was decreased (King 2000). Reduced colostrum and milk intake were negative effects on piglets, for example raising pre-weaning mortality (Vasdal et al. 2011) and decreasing the average pre-weaning weight gain (Auldist et al. 1998). The use of nurse sows, artificial rearing systems, or milk supplements can provide the opportunity to keep these large litters. The addition of liquid milk supplementation may increase the piglet's nutrient intake and increase weight gain (Ha et al. 2011). Weaning weight is related to birth weight (Wolter and Ellis 2001) and to the amount of sow's milk which was consumed by piglets during lactation (Lewis et al. 1978) It is known that the weaning weight of suckling pigs is correlated with post weaning growth rate (McConnell et al. 1987, Mahan and Lepine 1991, Mahan et al. 1998, Klindt 2003), the weaning weight can be increased by providing a supplemental milk replacer (Azain et al. 1996, King et al. 1998, Dunshea et al. 1999, Wolter et al. 2002). The developed liquid milk supplementary has positive effects on the rate of growth; on the balance of the stock and on the weaning weight (Azain et al. 1996). The carbohydrate metabolism is determining process on the piglet's growth rate.

The aim of this review is to overview the hormonal factors which have role on the regulation of feed intake. These parameters regulate the nutrient intake and the growth of piglets at the pre-weaning period.
The anabolic and catabolic processes of the carbohydrate metabolism are regulated by insulin, insulin-like growth factor 1 (IGF-1), and growth hormone $(\mathrm{GH})$ growth hormone releasing hormone, leptin, ghrelin. In this review we illustrate these hormones individual and combined roles. We also investigate the effect of liquid milk supplementation on growth and the how the hormone regulating system is changed.

\section{ROLES OF INSULIN, IGF-1, GH, GHRH, LEPTIN GHRELIN}

\section{Insulin}

The insulin belongs to the family of insulin-like growth facorts (IGFs). The all known vertebrate insulin analogs have a classical structure with three $100 \%$ conserved disulfide bonds that are essential for structural stability and thus the function of insulin (Tine et al. 2012). The classical insulin which is shared by members of the insulin super-family includes three $\alpha$-helices, two in the A chain and one in the B-chain, and a hydrophobic core of non-polar residues which are important for folding and maintaining the structure (Baker et al. 1988, WHO 1999). Insulin regulates the storage of nutrients as anabolic hormone; reduce the breakdown of stored nutrients. Insulin determines how high the glucose is and the free fatty acid levels of the blood. Insulin inhibits the production of hepatic glucose, increases glucose uptake in fat and muscle so the insulin is the primary regulator of the glucose concentration of blood. Insulin stimulates cell growth and cell differentiations, furthermore stimulates the synthesis of protein and glycogen, lipogenesis, and inhibits the breakdown of protein, glycogenolysis and lipolysis (Saltiel and Kahn 2001). The genetic and environmental/epidemical factors influence the synthesis and secretion of insulin (Kaiyala et al. 2000). 


\section{IGF-1}

In addition to insulin, the plasma contains insulinlike growth factors which have insulin-like effects. Moreover these factors have both in vitro (cell culture) and in vivo growth promoting effects, the structure of proinsulin, IGF-1, IGF-2 shows significant similarities. Both IGFs contain homologous details of proinsulin/insulin A and B chains. Like proinsulindespite of insulin- in the IGFs have smaller variant of $\mathrm{C}$ peptide linking $\mathrm{A}$ and $\mathrm{B}$ chain, with 11 amino acids in IGF-1 and 8 amino acids in IGF-2. The IGFs is synthesized in a wide variety of cells. IGF-1 detected in plasma is derived from hepatocytes and its secretion regulated by the growth hormone of adenohypophysis. Local production of IGF-1 plays a major role to the growth of tissues and due to the overall pattern of IGF production during development IGF-1 is considered to be more important for postnatal growth and development than insulin or IGF-2. IGF-1 might be a potential mediator of vascular growth response (Griffeth et al. 2014).

\section{Growth hormone, GHRH}

Growth hormone consists of 191-amino acids, it is single-chain polypeptide which is synthesized, stored, and secreted by somatotropic cells within the lateral wings of the anterior pituitary gland (Carter-Su et al. 1996). According to its name one of the most important regulatory of growth but it is also regulating several metabolic processes. GH has effect on lots of tissues such as adipose tissue, liver tissue, and muscle tissue. GH induces the secretion of IGF-1 in the liver, increase the secretion of glucagon, and reduce the sensitivity of insulin on peripherial tissues, in the adipose tissues synergists to lipolytic hormones thanks to that increase the plasma free fatty acid concentration. The growth hormone secretion is basically controlled by a stimulating (GHRH) (Plotsky and Vale 1985) and an inhibitory (somatostatin) hypothalamus hormone, based on metabolism factors, peripheral stimuli and feedback regimens. GHRH of the hypothalamus enhances the secretion of GH and additionally transcription of the $\mathrm{GH}$ gene (Lin-Su and Wajnrajch 2002). The inhibitory hormone, somatostatin, has no effect on transcription and hormone synthesis but determines the timing and amplitude of secretion episodes (Muller et al. 1999). Growth hormone has several immediate effects on tissues that play a role in energy storage. Although secretion of growth hormone often happens during sleep, it is also secreted when blood sugar is low. This may seem counter-intuitive, but it's because growth hormone helps induce lipolysis. It induces fat cells to release fatty acids, stimulates the liver to release glucose, and triggers muscle cells to take up glucose and amino acids so as to promote muscle proliferation. In other words, growth hormone promotes the use of fat stores to build up muscle (Net1).

GHRH is a 44 amino-acid polypeptide produced in the arcuate nucleus of the hypothalamus. These neuronal terminals secrete GHRH to reach the anterior pituitary somatotrophs via the portal venous system, which leads to GH transcription and secretion. GHRH plays a vital role in the proliferation of somatotrophs in the anterior pituitary, where the absence of GHRH has, in fact, lead to anterior pituitary hypoplasia. The secretion of GHRH is stimulated by several factors (Gunawardane et al. 2015).

\section{Gherlin}

Ghrelin is a peptide hormone, which proteolytically processed to a 28-amino acid peptide $(3.3 \mathrm{kDa})$. A post synthetic modification takes place in which an $n$-octanoic acid residue is bound to one of the amino acids; this modification is necessary for biological activity. Synthesis occurs predominantly in epithelial cells lining the fundus of the stomach; only small amounts are produced in the placenta, kidney, pituitary, and hypothalamus (Meier and Gressner 2004).

Ghrelin has hormonal, cardiovascular, metabolic, immunological effects and also effects on the autonomic nervous system and musculoskeletal system (Higgins et al. 2007). It has adipogenic, orexigenic and somatotropic properties, increasing feed intake and body weight. The ghrelin has a role as a brain-gut peptide and emphasizes the significance of vagal afferent fibers a major pathway to the brain.

\section{Leptin}

Leptin is a $16 \mathrm{kDa}$ protohormone named after the Greek "leptos", meaning thin (Clement et al. 1996, Reed et al. 1996). More than 20 amino acid sequence of leptin from a wide spectrum of species are available. Predominantly It is produced in adipose tissue and circulated in serum both as protein-bound and as free entity, although production has been demonstrated in other tissues such as the fundus of the stomach, the skeletal muscle, the liver, and the placenta. Leptin is a member of growth hormone fourhelical cytokine subfamily. It has role in lot of biological activities such as angiogenesis, blood pressure, bone mass, lymphoid organ homeostasis and $\mathrm{T}$ lymphocyte function. Leptin has an integral signaling mechanism to influence proper physiological control of biological functions (La Cava et al. 2003, 2004, Yuan et al. 2004). The leptin receptor is expressed in the central nervous system, as well as wide spectrum of peripherial tissues The leptin receptor characterized as a member of the class I cytokine receptor family (Zhang et al. 2005). Leptin has shown to have strong influence on several endocrine axes.

\section{HORMONE INTERACTIONS}

\section{GH and IGF-1 relationship}

It was thought that IGF was produced only by the liver and its expression was fully dependent on GH. Nowadays we know this peptide produced, as it occurs with GH, practically in all cells and tissues, where it plays an auto/paracrine role. Moreover, IGF-I antibodies can block the proliferative effects of $\mathrm{GH}$, indicating a local IGF-I action dependent on GH stimulation of local IGF-I production (Jux et al. 1998) Taken together, these findings indicate that $\mathrm{GH}$ acts 
directly on chondrocyte stem cells and also promotes chondrocyte proliferation via local IGF-I production. IGF-I then would stimulate clonal expansion of proliferating cells in an auto/paracrine manner (Devesa et al. 2016)

\section{„Glucose loop theory"}

In our previous experiment we got the results shown below (Table 1-2). In this study we took samples from pig group fed with milk replacers and also from control group. All groups had 22 members. Growth hormone, thyroid hormones, insulin, IGF and sex hormones have high role in the growth and development of pigs. Growth also determined by genetical background, the quality and quantity of feeding, and also by the environmental impacts. Our results were explained by the „GLUCOSE LOOP THEORY" (Figure 1).

Figure 1: ,The glucose-loop theory"

\section{"GLUCOSE-LOOP”}

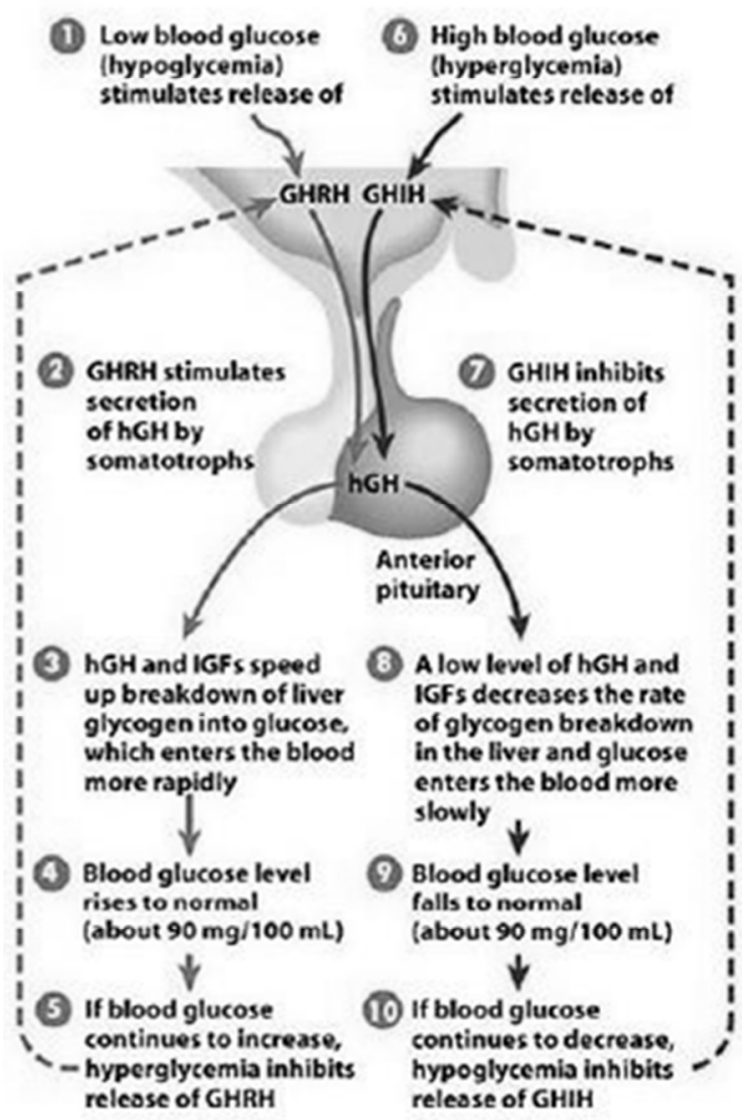

Source: Linte Robbins John Wiley \& Sons Inc.

In case of direct metabolic effect, GH inhibits glucose uptake in adipose tissue, skeletal muscles. It also raises gluconeogenesis and glycogen metabolism in liver therefore it raises blood sugar level. Beyond that GH enhances lipolysis, FFA and ketone bodies concentration in blood plasma (Kuo et al. 2015).
Direct metabolic effects come to the fore in case of low calorie ingestion and energy mobilization.

Indirect metabolic effects of $\mathrm{GH}$ come to the fore in case of high protein and lipid contained forage additive usage. In this case anabolic processes are highlighted. $\mathrm{GH}$ enhances protein uptake in skeletal muscles and in the liver, therefore the level of amino acids in blood plasma decreases. It also enhances protein synthesis, structural protein synthesis in the skeletal muscles, therefore it leads to positive nitrogen balance (Spencer 1984).

The explanation of significantly higher insulin and IGF concentration as well as decreased GHRH level is the "glucose-loop "theory.

Due to continual nutriment intake, insulin level permanently high provokes hunger in animal's organism. Because of low blood sugar level, GHRH secretion induced which stimulates somatotropproduced GH. GH and IGF-1 speeds up glucoseglygocen transformation. Insofar as blood sugar level keeps on rise hyperglycemia induces, therefore GHRH secretion stops. High blood sugar level stimulates GHIH secretion which inhibits $\mathrm{GH}$ production. Because of low GH and IGF-1 level glycogen metabolism decreases, therefore glucose gets into blood slower. As blood sugar level normalizes, GHIH secretion stops.

Because of the elevated protein intake and hypocaloric status, growth stimulation effect predominates of the GH. That is the explanation why nutriment exploitation is significantly higher in treated group in spite of lower GHRH (Asbóth et al. 2016).

\section{Ghrelin and leptin}

Ghrelin stimulates food intake in mammalian and appears to act as the functional antagonist of leptin (Zigman and Elmquist 2003) there is a fine balance between the two physiologically antagonistic hormones. Moderate leptin administration prevents the increase of plasma ghrelin during short-term energy restriction. In contrast to leptin, plasma levels of ghrelin fluctuate in relation to food intake. The low ghrelin levels are associated with low growth hormone concentration and high leptin levels. On the other hand, the sleep-week behavior effects on ghrelin and leptin regulation. Bad quality of sleep is associated with changed levels of ghrelin and leptin and is in connection with energy balance disorders leading to weight-gain (Somogyi et al. 2017).

Insulin has a temporal relationship with postprandial ghrelin concentrations: insulin levels rise as ghrelin levels fall. Various studies have been done to try to determine whether or not there is also a functional relationship, and whether or not glucose levels are a factor in this equation. Three of the studies concluded that insulin does induce the postprandial fall in ghrelin levels (Saad et al. 2002, Flangan et al. 2003, Murdulo et al. 2003), and one of them showed that not only is insulin able to induce this fall, but also that it is in fact a prerequisite for it (Murdolo et al. 2003). One study examined whether it was truly the change in insulin levels, or merely the associated change in glucose levels that led to this effect, and 
concluded that changing insulin levels alone were sufficient to cause the postprandial drop, but that hyperglycaemia may have an additional effect (Flanagan et al. 2003). Other research contradicts this by showing that the control of ghrelin release is mediated by the presence or absence of nutrients within the gastro intestinal tract and is not affected by insulin levels (Higgins et al. 2007).

Average weight of piglets

\begin{tabular}{lcccccc}
\hline & \multirow{3}{*}{ Group } & \multicolumn{3}{c}{ Number of piglets (n) } & \multicolumn{3}{c}{ Average weight $(\mathrm{kg})$} \\
\cline { 2 - 7 } & 1. day & $2-14$. day & $15-28$.day & 1. day & $2-14$. day & 15-28. day \\
\hline Control & 363 & 333 & 321 & 1.40 & $4.11^{\text {a }}$ & $7.38^{\text {a }}$ \\
Treated & 347 & 330 & 318 & 1.40 & $4.76^{\text {b }}$ & $8.38^{\text {b }}$ \\
\hline
\end{tabular}

Source: own data. Note: Treated: The piglets got Milk Supplement (MS) in 16.6\% weight percentage solution: $2.0 \mathrm{~kg}$ dry milk powder was added to 101 water. Control: The piglets in control group were sucking from birth till weaning (day 28), and they got pre-starter feed from day ad libitum.

Milk replacement effect on the concentration of carbohydrate metabolism hormones

\begin{tabular}{lccccccccc}
\hline \multirow{2}{*}{ Group } & \multirow{2}{*}{$\begin{array}{c}\text { Number of } \\
\text { piglets }(\mathrm{n})\end{array}$} & \multicolumn{2}{c}{ Glucose $(\mathrm{mM})$} & \multicolumn{2}{c}{ GHRH $(\mathrm{pg} / \mathrm{mL})$} & \multicolumn{2}{c}{ IGF-1 $(\mathrm{ng} / \mathrm{mL})$} & \multicolumn{2}{c}{ Insulin $(\mathrm{pg} / \mathrm{mL})$} \\
\cline { 3 - 9 } & 22 & Average & SEM & Average & SEM & Average & SEM & Average & SEM \\
\hline Control & 22 & 7.72 & 0.57 & $11.53^{\mathrm{a}}$ & 0.46 & $155.38^{\mathrm{a}}$ & 9.05 & $30.78^{\mathrm{a}}$ & 3.11 \\
Treated & 6.79 & 0.46 & $8.74^{\mathrm{b}}$ & 0.30 & $202.54^{\mathrm{b}}$ & 14.32 & $47.02^{\mathrm{b}}$ & 4.36 \\
\hline
\end{tabular}

Source: own data

\section{CONCLUSION}

The aim of this review was to overview the hormonal factors which have role on the regulation of feed intake. We also interested in how milk supplementation effect on carbohydrate metabolism. We are going to find that many hormones contribute to nutrition. Characterization of these hormones reveals that they perform many functions. We would like to know that what hormone roles are highlighted when piglets get liquid milk supplementation ad libitum. From our previous study (Novotni-Dankó et al. 2015, Asbóth et al. 2016), it was found that supplementation helped to compensate for litter, and despite the fact that growth hormone releasing hormone was higher than the treated group, average weight gain was significantly higher in the treated group. This is explained by the so-called "sugar loop" principle where the anabolic effect of GH highlighted. There is a need for further studies on how these processes correlate to ghrelin and leptin.

\section{ACKNOWLEDGEMENTS}

The work/publication is supported by the EFOP3.6.3-VEKOP-16-2017-00008 project. The project is co-financed by the European Union and the European Social Fund.

\section{REFERENCES}

Algers, B.-Jensen, P. (1985): Communication during suckling in the domestic pig - effects of continuous noise. Appl. Anim. Behaviour Science. 14: 49-61.

Asbóth G.-Novotniné Dankó G.-Győri Zs.-Balogh P.-Remenyik J. (2016): Folyékony tejpótló kiegészítés hatása szopós malacok szénhidrát anyagcseréjét szabályozó hormonokra. XXXVI. Óvári Tudományos Nap. „Hagyomány és innováció az agrár- és élelmiszergazdaságban” Mosonmagyaróvár, 2016. november 10. 276.

Auldist, D.-Morrish, L.-Eason, P.-King, R. (1998): The influence of litter size on milk production of sows. Animal Science. 67: 333-337.

Azain, M. J.-Tomkins, T.-Sowinski, J. S.-Arentson, R. A.-Jewell, D. E. (1996). Effect of supplemental pig milk replacer on litter performance: seasonal variation in response. Journal of Animal Science. 74: 2195-2202.

Baker, E. N.-Blundell, T. L.-Cutfield, J. F.-Cutfield, S. M.Dodson, E. J.-Dodson, G. G.-Hodgkin, D. M.-Hubbard, R. E.Isaacs, N. W.-Reynolds, C. D.-Sakabe, K.-Sakabe, N.-
Vijayan, N. M. (1988): The structure of 2Zn pig insulin crystals at 1.5. A resolution. Philos Trans R Soc Lond B Biol Sci. 319: 369-456.

Carter-Su, C.-Swarttz, J.- Smit, J. (1996): Molecular mechanism of growth hormone action. Annual reviews of Physiology. 58: 187-207.

Clement, K.-Garner, C.-Hager, J.-Philippi, A.-Le Duc, C.-Carey, A.-Harris, T. J.-Jury, C.-Cardon, L. R.-Basdevant, A.Demenais, F.-Guy $\square$ Grand, B.-North, M.-Froguel, P. (1996): Indication for linkage of the human $\mathrm{OB}$ gene region with extreme obesity. Diabetes. 45: 687-690.

Daltiel, A. R.-Kahn, C. R. (2001): Insulin signalling and the regulation of glucose and lipid metabolism. Nature. 414: 799806.

Devesa, J.-Almengló, C.-Devesa, P. (2006): Multiple Effects of Growth Hormone in the Body: Is it Really the Hormone for Growth? Clinical Medicine Insights: Endocrinology and Diabetes. 2016. 9: 47-71. 
Dunshea, F. R.-Kerton, D. J.-Eason, P. J.-King, R. H. (1999): Supplemental skim milk before and after weaning improves growth performance of pigs. Australian Journal of Agricultural Research. 50: 1165-1170.

Flanagan, D. E.-Evans, M. L.-Monsod, T. P.-Rife, F.-Heptulla, R. A.-Tamborlane, W. V. (2003): The influence of insulin on circulating ghrelin. Am. J. Physiol. Endocrinol. Metab. 284: E313-316.

Griffeth, R. J.-Bianda, V.-Nef, S. (2014): The emerging role of insulin-like growth factors in testis development and function. Basic and Clinical Andrology. 24: 12.

Ha, D. M.-Jang, K. S.-Won, H. S.-Ha, S. H.-Park, M. J.-Kim, S. (2011): Effects of creep feed and milk replacer and nursery phase-feeding programs on pre- and post-weaning growth of pigs. Han'gug Dongmul Jawon Gwahag Hoeji. 53: 333-339.

Higgins, S. C.-Gueorguiev, M.-Korbonits, M. (2007): Ghrelin, the peripheral hunger hormone. Annals of Medicine. 39: 116-136.

Jux, C.-Leiber, K.-Hügel, U. (1998): Dexamethasone impairs growth hormone $(\mathrm{GH})$-stimulated growth by suppression of local insulin-like growth factor (IGF)-I production and expression of GH- and IGF-I-receptor in cultured rat chondrocytes. Endocrinology. 139: 3296-3305.

Kaiyala, K. J.-Prigeon, R. L.-Kahn, S. E. (2000): Obesity induced by a high-fat diet is associated with reduced brain insulin transport in dogs. Diabetes. 49: 1525-1533.

King, R. H. (2000): Factors that influence milk production in wellfed sows. J. Animal Sci. 78: 19-25.

King, R. H.-Boyce, J. M.-Dunshea, F. R. (1998): Effect of supplemental nutrients on the growth performance of suckling pigs. Australian Journal of Agricultural Research. 49: 883-887.

Klindt, J. (2003): Influence of litter size and creep feeding on preweaning gain and influence of preweaning growth on growth to slaughter in barrows. Journal of Animal Science. 81: 2434-2439.

Kuo, T.-McQueen, A.-Chen, T. C.-Wang, J. C. (2015): Regulation of Glucose Homeostasis by Glucocorticoids. Adv. Exp. Med. Biol. 872: 99-126.

La Cava, A.-Alviggi, C.-Matarese, G. (2004): Unraveling the multiple roles of leptin in inflammation and autoimmunity. $\mathrm{J}$. Mol. Med. 82: 4-11.

La Cava, A.-Matarese, G.-Ebling, F. M.-Hahn, B. H. (2003): Leptin $\square$ based immune intervention: Current status and future directions. Curr. Opin. Investig. Drugs. 4: 1327-1332.

Lin-Su, K.-Michael, P. (2002): Wajnrajch Growth Hormone Releasing Hormone (GHRH) and the GHRH Receptor. Reviews in Endocrine \& Metabolic Disorders. 3: 313-323.

Mahan, D. C.-Cromwell, G. L.-Ewan, R. C.-Hamilton, C. R.-Yen, J. T. (1998): Evaluation of the feeding duration of a phase 1 nursery diet to three-week-old pigs of two weaning weights. Journal of Animal Science. 76: 578-583.

Mahan, D. C.-Lepine, A. J. (1991): Effect of pig weaning weight and associated nursery feeding programs on subsequent performance to 105 kilograms body weight. Journal of Animal Science. 69: 1370-1378.

McConnell, J. C.-Eargle, J. C.-Woldorf, R. C. (1987): Effects of weaning weight, co-mingling, group size and room temperature on pig performance. Journal of Animal Science. 65: 12011206.
Muller, E. E.-Locatelli, V.-Cocchi, D. (1999): Neuroendocrine control of growth hormone secretion. Physiol Rev. 79: 511607.

Murdolo, G.-Lucidi, P.-Di Loreto, C.-Parlanti, N.-De Cicco, A.Fatone, C. (2003) Insulin is Required for Prandial Ghrelin Suppression in Humans. Diabetes. 52: 2923-2927.

Net1: http://ouopentextbooks.org/biol3103/ (2017. 11. 18.)

Novotni-Dankó, G.-Balogh, P.-Huzsvai, L.-Győri, Zs. (2015): Effect of feeding liquid milk supplement on litter performances and on sow backfat thickness change during the suckling period. Arch. Anim. Breed. 58: 229-235.

Plotsky, P. M.-Vale, W. (1985): Patterns of growth hormonereleasing factor and somatostatin secretion into the hypophysial-portal circulation of the rat. Science. 230: 461463.

Reed, D. R.-Ding, Y.-Xu, W.-Cather, C.-Green, E. D.-Price, R. A. (1996): Extreme obesity may be linked to markers flanking the human OB gene. Diabetes. 45: 691-694.

Saad, M. F.-Bernaba, B.-Hwu, C. M.-Jinagouda, S.-Fahmi, S.Kogosov, E. (2002): Insulin regulates plasma ghrelin concentration. J. Clin. Endocrinol. Metab. 87: 3997-4000.

Sandøe, P.-Rutherford, K.-Berg, P. (2012): Large litter sizes ethical challenges and ways of dealing with them in future breeding and management. Bruges, Belgium. Proceedings of the 4th European Symposium of Porcine Health Management. 74-76.

Spencer, G. S. G. (1984): Hormonal systems regulating growth. Livestock Production Science. 12. 1: 1-46

Vasdal, G.-Ostensen, I.-Melisova, M.-Bozdechova, B.-Illmann, G.-Andersen, I. (2011): Management routines at the time of farrowing-effects on teat success and postnatal piglet mortality from loose housed sows. Livestock Sci. 136: 225-231.

Vinther, T. N.-Norrman, M.-Ribel, U.-Huus, K.-Schlein, M.Steensgaard, D. B.-Pedersen, T. A.-Pettersson, I.-Ludvigsen, S.-Kjeldsen, T.-Jensen, K. J.-Hubalek, F. (2012): Insulin analog with additional disulfide bond has increased stability and preserved activity. The Protein Society. 22. 3: 296-305.

Wolter, B. F.-Ellis, M.-Corrigan, B. P.-DeDecker, J. M. (2002): The effect of birth weight and feeding of supplemental milk replacer to piglets during lactation on preweaning and postweaning growth performance and carcass characteristics. Journal of Animal Science. 80: 301-308.

World Health Organization (1999): Definition, Diagnosis and Classification of Diabetes Mellitus and its Complications. Part 1: Diagnosis and Classification of Diabetes Mellitus. WHO Consultation. Geneva: World Health Organization, Department of Noncommunicable Disease Surveillance. 553.

Yuan, S. S.-Tsai, K. B.-Chung, Y. F.-Chan, T. F.-Yeh, Y. T.-Tsai, L. Y.-Su, J. H.-Chen, H. W.-Chang, H. L.-Huang, C. H. (2004): Aberrant expression and possible involvement of the leptin receptor in endometrial cancer. Aberrant expression and possible involvement of the leptin receptor in bladder cancer. Gynecol. Oncol. 92: 769-775.

Zhang, F.-Chen, Y.-Heiman, M.-DiMArchi, R. (2005): Leptin: Structure, Function and Biology in Vitamins \& Hormones. 71: 345-372.

Zigman, J. M.-Elmquist, J. K. (2003): Minireview: from anorexia to obesity - the yin and yang of body weight control. Endocrinology. 144: 3749-3756. 